\title{
Tourism Development Strategy of Buntula'bi Balusu Sub-village, North Toraja Regency Based on Tourist Perception
}

\author{
Vica Vanessa Sesaryo Timang ${ }^{1}$, Antariksa ${ }^{2}$, Ismu Rini Dwi Ari ${ }^{2}$ \\ ${ }^{1}$ Master Program of Urban and Regional Planning, Faculty of Engineering, University of Brawijaya, Malang \\ ${ }^{2}$ Department of Urban and Regional Planning, Faculty of Engineering, University of Brawijaya, Malang
}

\begin{abstract}
Buntula'bi Balusu Sub-village located in North Toraja Regency. It is uniquely endowed with diverse cultural heritages, both physical (tangible) and non-physical (intangible) cultures, viable to attract domestic and/or international tourists. The objectives of this research were to identify Buntula'bi physical and non-physical characteristics, analyse the tourists' perceptions towards Buntula'bi's tourism objects performances, and formulate the appropriate direction of tourism development within the sub-village. The research employed descriptive and evaluative analytical methods through observations on primary data, questionnaires, documentation, and a set of literature reviews. An evaluative approach was used to measure tourists' level of satisfaction towards the tourism objects performances. Tourism component variables were assessed using Importance Performance Analysis (IPA). Descriptively, the physical characteristics in the study site were in the form of ancestral buildings, which included tongkonan Kollo-Kollo, tongkonan Rantewai, togkonan Lingkasile, alang, banuabugi', and also traditional buildings of kombongan, rantetendan, ranteissun, liangtondon, lokkotarra, and sawahadat. Meanwhile, the non-physical characteristics were identified as indigenous traditions in the forms of tribal cultures and ceremonies such as Aluk Todolo, Rambu Solo' and RambuTuka'. The IPA result showed that the top priority for the tourism development strategy in Buntula'bi was to improve public facilities, optimize road conditions, and develop restaurants and accommodation, as well as souvenir shops in Buntula'bi Balusu Sub-village.
\end{abstract}

Keywords: Importance Performance Analysis, tourism development, Toraja.

\section{INTRODUCTION}

Cultural tourism in the tourism domain is a type of tourism resulting from a cultural attraction of a particular region. In living culture, the plausible elements to become attractions include the tribal traditions, religious rituals or ceremonies, and art performances. Whereas in cultural heritage, attractions can be in the form of historical artefacts, cultural landscapes, and many others [1]. Due to its uniquely distinctive heritage, Toraja has captivated countless domestic and international tourists' attention. Balusu is one of the regions in Northern Toraja Regency which is rich in such cultural heritage. This region consists of three smaller Sub-village, namely Kalumpang, Buntula'bi, and Solo'. Amongst them, Buntula'bi Sub-village is chosen as a study area because of the existence of many ancestral buildings and traditional villages conceivable for future tourism development in its site.

\footnotetext{
* Correspondence address:

Vica Vanessa Sesaryo Timang

Email : Veeca_vanessa@yahoo.com

Address : Master Program of Urban and Regional Planning, University of Brawijaya, Jl. Veteran Malang 65145
}

According to the 2013 data of The Department of Culture and Tourism of Northern Toraja, in spite of being not designated yet as an official Indonesian heritage site, some artefacts in this sub-village have been listed in the Northern Toraja heritage sites' list. The artefacts include the Tongkonan Balusu (inventory number 1022) and Tongkonan Kollo-Kollo (inventory number 1012).

Despite of its tourism potential to be developed, Buntula'bi Sub-village has not received significant attention from Indonesian government. Neither, initiatives from the local government is noticeable. This can be seen from the negligible government participation in preserving the ancestral buildings and developing the tourism objects, as well as the few available supporting tourism facilities such as restaurants and accommodations. Given this condition, therefore it is important for this research to explore Buntula'bi Hamlet's tourism potential in order to formulate an appropriate sustainable development strategy. 


\section{MATERIALS AND METHODS}

\section{Study Area}

Buntula'bi Sub-village located in the Village of Balusu, Balusu Sub-district, North Toraja Regency, South Sulawesi Province. The total area of Buntula'bi Sub-village is approximately 250 ha with mountainous and hilly topography. Other geographical characteristics include: an altitude of $890 \mathrm{~m}$ asl, steepness level of $8-25 \%$, rainfall intensity of $3,645 \mathrm{~mm}$ per year, a temperature range of $14-25^{\circ} \mathrm{C}$, and humidity level of $82-86 \%$. Demographically, this sub-village is home for a relatively small population, about 419 residents.

The viable tourism potencies are ancestral buildings, traditional villages, traditional art performances, tribal rituals and ceremonies, such as funeral ceremony which locally known as Rambu Solo' and thanksgiving ceremony known as RambuTuka'. Rituals and ceremonies in Balusu are the most anticipated ceremony by tourists to date because Balusu considered as the land for nobles that suggests a significantly more elaborate standard for traditional ceremonies.

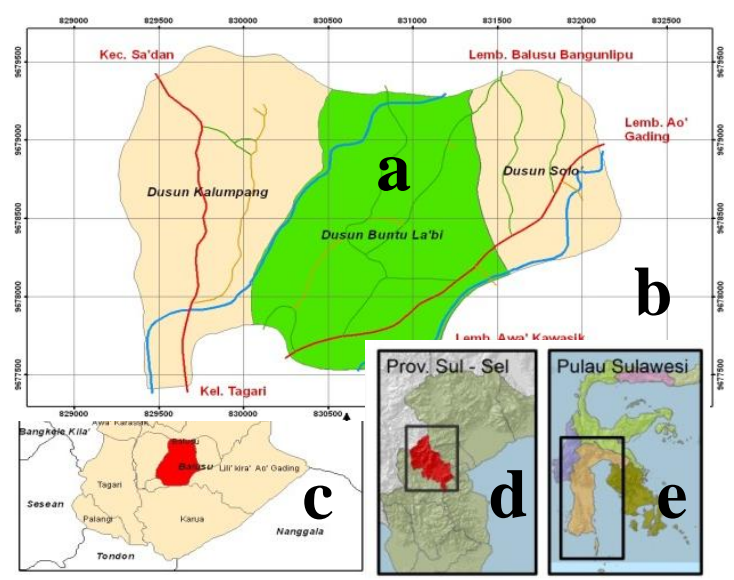

Figure 1. Study Area of Buntula'bi Sub-village Description:

a. Buntula'bi Sub-village

b. Balusu Village

c. Balusu Sub-district

d. North Toraja Regency

e. South Sulawesi Province

\section{Data Analysis}

This research employed a quantitative descriptive analytical method. It can be explained as a methodology based on positivism and used as a means to assess a particular population or sample [2]. The determination of tourist sample number for this research was done using the Sample Linear Time Function [3] ( $n=(T-$ to $) / t i)$, which was 35 tourist respondents.

\section{Physical and non-physical characteristic}

Using an explorative descriptive analytical method, this method covers analysis on land use, traditional village, traditional ritual and ceremony.
The explorative descriptive approach explains actual phenomenal characteristics. It also comprehends the actual phenomena by the assessment on a set of alternatives in order to suggest new initiatives through observations, interviews, and questionnaires [4].

Respondents were traditional leaders who controlled the history, knowledge, ancient buildings and attractions in the sub-village or village head of Buntula'bi and understand the context of cultural tourism. The questions were focused to determine the condition of the building and the environment, Toraja culture and the relationship between the utilization of space, and the validity of traditions, rituals and ceremonies.

\section{Importance Performance Analysis (IPA)}

This method was used to analyze tourists' perceptions towards the attributes of tourism objects' performances in order to formulate a tourism development strategy in Buntula'bi Subvillage.

IPA is a combination of perceptions towards the satisfaction and importance level [5]. Using a Likert scale with 5 different levels: very unimportant, unimportant, somewhat important, important, and very important.

The equation for this method is:

$$
T k i=\frac{X i}{Y i} X 100 \%
$$

$$
\begin{aligned}
\text { Description: } & \\
\mathrm{Tki} & =\text { parallel level } \\
\mathrm{Xi} & =\text { satisfaction score } \\
\mathrm{Yi} & =\text { importance score }
\end{aligned}
$$

Furthermore, in the Cartesian coordinate diagram, the $X$ axis in the satisfaction level, whereas, the $Y$ axis is the importance level based upon the following equations.

$$
X=\frac{\Sigma X i}{n} \quad Y=\frac{\Sigma Y i}{n}
$$

Description:

$X=$ average score for satisfaction level

$Y=$ average score for importance level

$\mathrm{n}=$ number of respondents.

To determine the objective margins represented by the coordinate of $x, y$, the following equations were used.

$$
\mathrm{X}=\frac{\sum_{\mathrm{i}=1} \overline{\mathbf{X}}_{\mathbf{i}}}{\mathrm{K}} \quad \mathrm{Y}=\frac{\sum_{\mathrm{i}=1} \overline{\mathbf{Y}}_{\mathbf{i}}}{\mathrm{K}}
$$

Description:

$\mathrm{K}=$ number of items or attributes scored by the respondents 
Consecutively, the average scores were then mapped in the Cartesian coordinate diagram which had been divided into 4 sections or quadrants (Fig. 2).

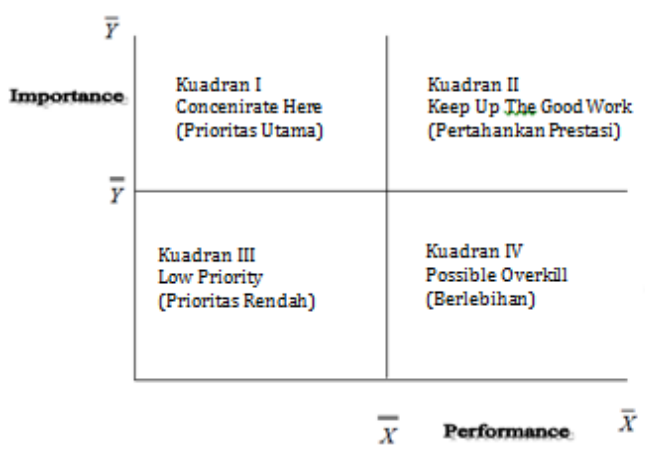

Figure 2. IPA Cartesian coordinate diagram Source: Bacon [6]

\section{RESULTS AND DISCUSSION \\ Land Use Pattern}

Land use in Buntula'bi Sub-village is dominantly utilized as dry agricultural land (160 ha, 64\%), rice farmland (55 ha, 0.55\%), and the remaining as settlements and public facilities (35 ha, 0.35\%) (Balusu Village Strategic Plan in 2011). The proportion of land use can be seen in Figure 3.

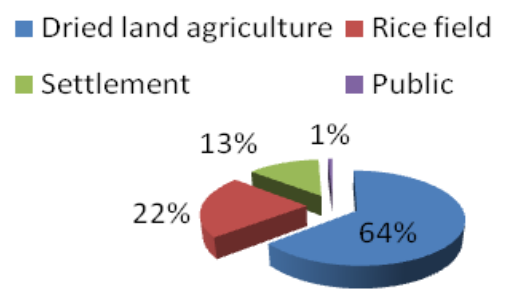

Figure 3. Land Use Pattern in Buntula'bi Sub-village

\section{Ancient buildings}

Tongkonan, the indigenous traditional house in Toraja, is such an exotically ancient type of building that attractive enough to draw the attention of tourists. The sub-village is home for at least 10 units of Tongkonan, each of which is owned by a group of families, namely Tongkonan of Lingkasile, Rantewai, Kollo-kollo, Bellolinggi, Lengkong, Malenong, Nusu L Limbong, Nenek Nita, $\mathrm{Ne}^{\prime}$ Masero and Tanete (Fig. 4).

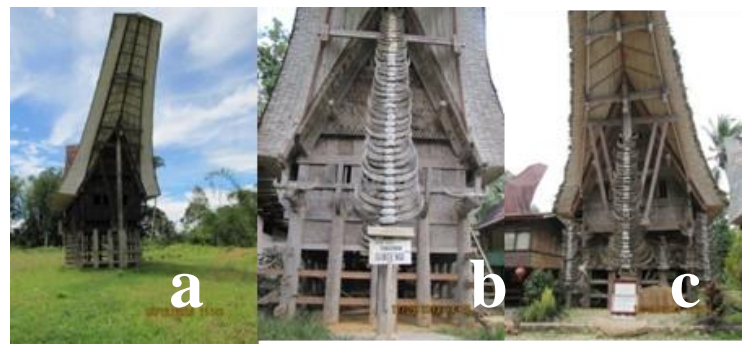

Figure 4. Tongkonan: a. Lingkasaile, b. Rantewai, c. KolloKollo
Total of 116 buildings units in the sub-village have been identified. The most dominant use of these units is as rice barns known as Alang, elevated or stage houses known as Banua' Bugi, modern houses, and ancestral houses known as Tongkonan, which accounts for $43.27 \%, 25 \%$, $16.35 \%$ and $15.38 \%$, respectively (Fig. 5).
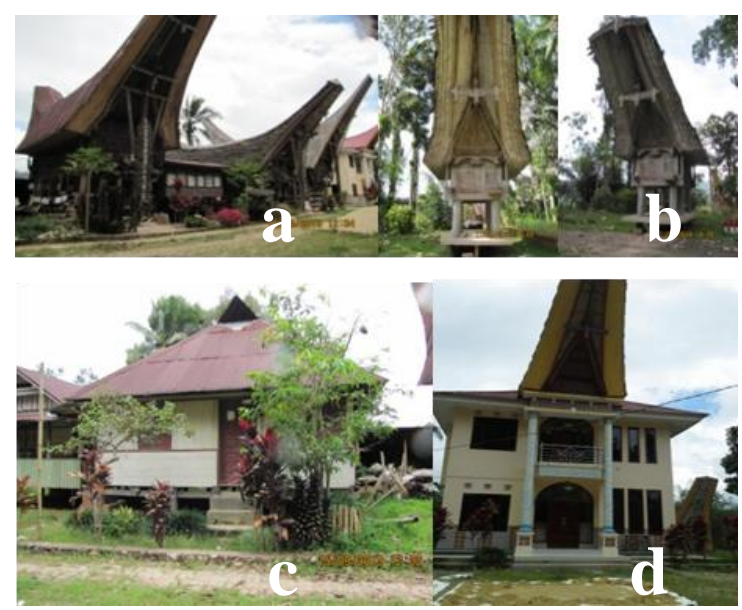

Figure 5. Ancestral buildings in Batula'bi Sub-village:
a. Tongkonan Kollo-Kollo
b. Alang at Tongkonan Rantewai
c. Banua' Bugi at Tongkonan Kollo-Kollo
d. Modern House at Tongkonan Kollo-Kollo

Tongkonan is Torajan north-south orienting traditional housing that functions as a residence, a knowledge centre, and an indigenous institution. Alang is a common name for rice barns and storage for other valuables which is located facing the Tongkonan. Banuabugi' is a wooden elevated house that functions as a private residence. Banuabiasa or modern house is also a private residence made of either wood or bricks. These four types of buildings commonly constitute a traditional Torajan neighborhood.

\section{Traditional Village}

A traditional village in Buntula'bi Sub-village consists of several elements, i.e. a community land known as Kombongan, venues to hold tribal ceremonies known as Rante Tendan and Rantelssun, stone graves known as Liang Tondon, natural caves known as Lokko Tarra, and community of rice farmlands. No particular arrangement of these traditional elements is found, however, each of them exists as an integral part of a Torajan traditional settlement (Fig. 6). 


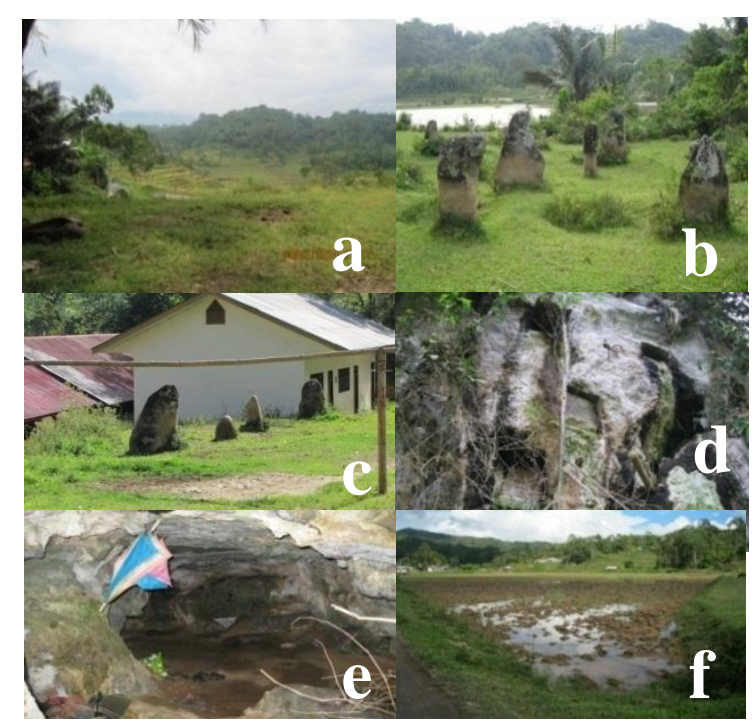

Figure 6. Traditional village:
a. Kombongan (community land)
b. Rante Tendan (venue for tribal ceremonies)
c. Rantelssun (venue for tribal ceremonies)
d. Liang Tondon (stone graves)
e. LokkoTarra (natural caves)
f. Community of rice farmland

\section{Traditional ceremony}

Traditional ceremonies are prevalent in every aspect of life in the Torajan society. Rambu' Solo and Rambutuka are some of the ceremonies that portray their indigenous beliefs [7].

\section{The Rambu Solo' ceremony (funeral ceremony)}

The Rambu Solo' ceremony is the most attractive ceremony for tourists, as seen from the satisfaction score of $4.29 \%$ and the importance score of $4.23 \%$. Rambu Solo' ceremonial is a sacred funeral ceremony in the ancestral beliefs, known as Aluk Todolo, with offerings of many sacrificial animals, such as buffalo and pigs for the dead as a tribal requirement that would guide his/her soul to the life after death. Table 1 explains the stages of Rambu Solo' ceremony.

Table 1. Stages of Rambu Solo' ceremony

\begin{tabular}{|c|c|c|c|}
\hline \multirow{2}{*}{$\begin{array}{l}\text { Day of the } \\
\text { occasion }\end{array}$} & \multicolumn{2}{|c|}{ Number of offerings } & \multirow{2}{*}{$\begin{array}{c}\text { Stages of Aluk Rambu } \\
\text { Solo' }\end{array}$} \\
\hline & Buffalos & Pigs & \\
\hline One day & - & - & Disili' \\
\hline Two days & - & $1-3$ & Dipasangbongi \\
\hline Three days & $1-2$ & $6-2$ & Dipatallubongi \\
\hline Four days & $3-5$ & $7-10$ & Dipalimangbongi \\
\hline Five days & $6-7$ & $11-20$ & Dipapitungbongi \\
\hline Six days & 8-11 & $21-40$ & Rapasan \\
\hline Seven days & $21-23$ & $41-50$ & Rapasansundun \\
\hline Eight days & $24-40$ & $51-100$ & Rapasansapurandanan \\
\hline
\end{tabular}

Source: Tulak [8]

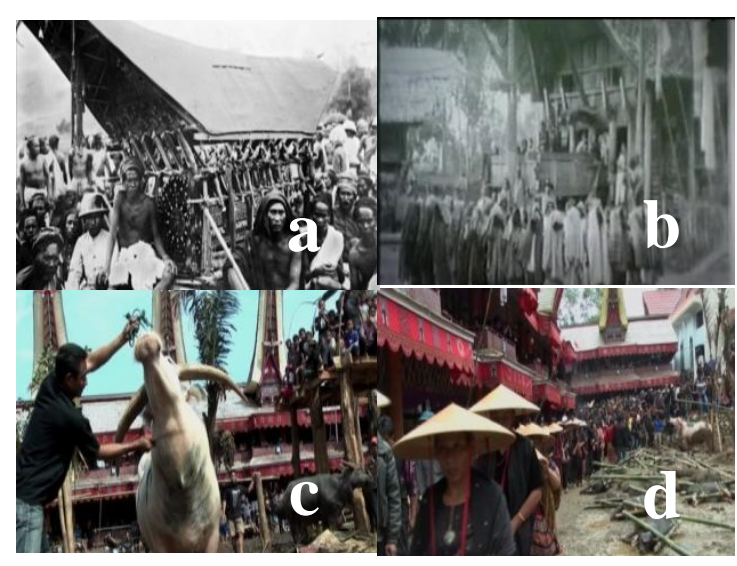

Figure 7. Rambu Solo' ceremony:
a. Rambu Solo' in the olden days
b. Ma'badong, a mandatory dance
c. Ma'tinggorotedong and d. Mantarimatamu, the guest welcoming

\section{Rambu Tuka' ceremony (thanksgiving ceremony)}

The ceremony is identified as a joyous thanksgiving ceremony, also known as Aluk Rampe Matallo or a religious ceremony conducted at the time when the sun is rising. It is commonly conducted in the morning times (eastern), either in the forms of a harvest feast, traditional house parties, or wedding ceremonials (Table 2).

Table 2. Types of RambuTuka' ceremony

\begin{tabular}{|c|c|}
\hline Type & Characteristic \\
\hline Mangrarabanua & $\begin{array}{l}\text { as a symbol of gratefulness to God } \\
\text { after building a house. }\end{array}$ \\
\hline$M a^{\prime}$ bugi' & $\begin{array}{l}\text { post-harvest, usually in community } \\
\text { scale. }\end{array}$ \\
\hline Merok & $\begin{array}{l}\text { to commemorate the death of a } \\
\text { nobleman; as a completion of a set of } \\
\text { funeral ceremonies by the close } \\
\text { relatives after the mourning period. }\end{array}$ \\
\hline Ma'bua' & $\begin{array}{l}\text { Similar in procedures and forms as } \\
\text { the Merok ceremony, however, not } \\
\text { all regions can afford holding this } \\
\text { ceremony due to its elaborated } \\
\text { nature, thus making it the most } \\
\text { interesting and substantial ceremony. }\end{array}$ \\
\hline Ma'sassiri & $\begin{array}{l}\text { in the form of a harvest festival and } \\
\text { considered as the closing of a funeral } \\
\text { commemoration for the middle-end } \\
\text { families. Commonly includes immola- } \\
\text { tion of 2-4 pigs. }\end{array}$ \\
\hline
\end{tabular}

\section{Characteristics of Tourism Components}

In general, tourism components consist of supply and demand. The following description is the explanation of supply and demand of tourism in the study area. 


\section{Tourism Objects}

The dominant tourism objects existed in Buntula'bi Sub-village are hundreds of year old Tongkonans, such as Tongkonan of Lingkasaile, Rantewai, Kollo-Kollo and Belolinggi'. There are also Kollo-Kollo museum, Rante Tendan, Liang Tondon and Lokko Tarra. The following table explains the characteristic of tourism objects in Buntula'bi Sub-village (Table 3).

Table 3. Tourism Objects of Buntula'bi Sub-village

\begin{tabular}{|c|c|}
\hline Object & Characteristics \\
\hline Tongkonan & an old Tongkonan ornamented with \\
\hline Kollo-kollo & $\begin{array}{l}\text { typical Torajan carving. Positioned at } \\
\text { the top of the Tongkonan is a museum } \\
\text { to keep the valuables of the ancestral } \\
\text { heritage, ranging from home } \\
\text { appliances, war equipment, to } \\
\text { jewellery. }\end{array}$ \\
\hline Tongkonan & a Tongkonan marked with a wooden \\
\hline Rantewai & $\begin{array}{l}\text { statue of a dragon-shaped head. The } \\
\text { dragon statue symbolises strength, } \\
\text { courage, and leadership. The eight in } \\
\text { number signifies that the owner is } \\
\text { known as the leader of the eight } \\
\text { directions of the compass in the village } \\
\text { and surrounding Balusu. }\end{array}$ \\
\hline Rante & a location for several menhirs in the \\
\hline Tendan & $\begin{array}{l}\text { Buntula'bi. Total of } 59 \text { units of } \\
\text { hundreds of year old menhirs in this } \\
\text { area were used as part of tribal } \\
\text { ceremonies by three Tongkonan, } \\
\text { namely Lingkasaile, Rantewai, and } \\
\text { Kollo-Kollo. }\end{array}$ \\
\hline Liang & stone grave on cliffs. These rocks were \\
\hline Tondon & $\begin{array}{l}\text { carved to resemble multi story cots, } \\
\text { locally known as liang. Each hole/box is } \\
\text { occupied by one's body of the nobles. }\end{array}$ \\
\hline Lokko & a natural cave that also used as graves \\
\hline Tarra & $\begin{array}{l}\text { for the common people other than the } \\
\text { nobels of Balusu. }\end{array}$ \\
\hline
\end{tabular}

\section{Tourist Attraction}

A tourist attraction is an attraction that able to attract tourists who want to visit [9]. The forms of attractions in Buntula'bi Sub-village include activities such as:

- Something to do (visiting the tongkonan, mountain tracking, cycling);

- Something to see (enjoying the natural beauty, visiting Liang Tondon, visiting Lokko Tarra, visiting Kollo-Kollo museum, and attending art performances)

- Something to memorize (witnessing rituals and ceremonies of Rambu Solo' and RambuTuka).

Detailed information about the traditional art as tourist attractions in Buntula'bi Sub-village showed in Table 4.
Table 4. Traditional Dances in Buntula'bi Sub-Village

Traditional
Dance

Rambu Tuka' (thanksgiving ceremony)

Ma' Gellu As the most popular dance, this dance is performed in ceremonies such as wedding celebration, harvest feast and guest welcoming. Performed by 5 or more female dancers using special costumes and accessories such as antique gold.

$\mathrm{Pa}^{\prime}$ Bonebala Similar to $M a^{\prime}$ Gellu except for the drum rhythms and the existence of a special song sung while dancing.

Ma'Dandan Performed by women dressed in complete white with traditional accessories known as Sa'pi (a head dress resembling Torajan house roof) as they dance to the music.

Manimbung The dance is performed by a man dress in black and accessorized by a matching headband made of chicken feathers. It is performed as a respect symbol to the late ancestors as harvest festival and a house party.

Manganda This dance is performed by a group of men wearing head dresses of a buffalo horn decorated with coins. Each of the dancers carries a small bell which is played interspersed with screams.

KelluTungga' This dance is performed with a chanting poem about a person's journey according to the person's social status. It is commonly performed at harvest celebrations.

\section{Rambu Solo' (the funeral ceremony)}

Ma'Badong Performed by a group of people forming a circle. In this dance, the dancers spin while a mourning song is played. It can be performed by both males and females. The dance tells a story of a human's life.

Memanna This dance is performed in a funeral ceremony of someone being murdered.

Ma'Jogge' Intended to welcome guests at the funeral of a noble person. Dancers are all dressed in black with a distinctive head dress known as Sa'pi.

$\mathrm{Pa}^{\prime}$ Pangan This dance is often performed by the girls to greet guests

Ma'Randing It danced to drop off and pick up guests at the funeral of the nobles. It danced by men with accessories such as attributes of war, e.g. spears, machetes and shields.

\section{Tourist Facilities}

A limited number of tourist facilities are found in Buntula'bi Sub-village. Tourists will find lack of accommodations, restaurants, toilets, travel agents and tour operators. In addition to those, unavailability of supporting facilities such as souvenir shops, ticketing lockets, and management office should be considered for further development. 


\section{Tourism Infrastructure}

Tourism infrastructures in the sub-village are generally provided in good condition. These include roads (access), water supply, sewerage, waste management, communication and drainage.

\section{Tourist}

Tourists' perceptions at tourist objects in Buntula'bi Sub-village is recapitulated according to their percentage and average scores toward each tourism attribute (Fig. 8).

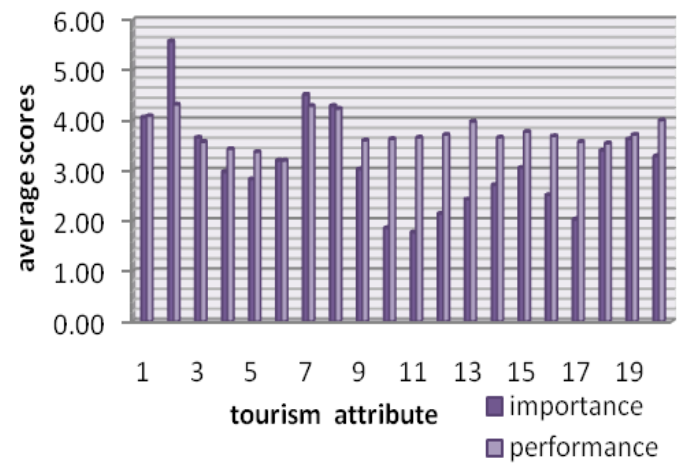

Figure 8. Satisfaction level and object's performance

Legend:

1. Natural beauty

2. Ancient buildings

3. Kollo-kollo museum

4. RanteTendan

5. LokkoTarra natural caves

6. Liang Tondon
7. Indigenous culture as a tourist attraction

8. Rambu Solo's rituals and ceremonies

9. Traditional art performances

10. Restaurants and accommodation

11. Souvenir shops

12. Public facilities (toilets and garbage bins)

13. Road condition

14. Transport mode to tourism objects

15. Infrastructure

16. Information

17. Tour guide service

18. Tourists' safety

19. Community participation

20. Tourism objects' management and preservation.

\section{Public}

Most of the Buntula'bi locals are inclined to the development of tourism in the sub-village as identified from $69 \%$ of the respondents. Demographically, the community comprises of $50.1 \%$ women, $57.28 \%$ Christians, and a significant $71.84 \%$ farmers.

\section{Tourists' perceptions toward the service of} performance attraction

The tourists' satisfaction level of the objects' performance in Buntula'bi Hamlet is based on the tourism components (Table 5 ). $X$ is the satisfaction value level, $Y$ is the importance value level, and Tik is the compatibility level.

Table 5. Saticfaction and Importance Levels of Tourist Objects in Buntula'bi Sub-Village

\begin{tabular}{|c|c|c|c|c|}
\hline No & IPA Attributes & Satisfaction level (X) & Performance level (Y) & Compatibility(\%) \\
\hline \multicolumn{5}{|c|}{ Tourism Object } \\
\hline 1 & Natural Beauty & 4.06 & 4.09 & 99.37 \\
\hline 3 & Kollo-Kollo museum & 3.66 & 3.57 & 102.40 \\
\hline 4 & RanteTendan (venue for tribal ceremonies) & 2.97 & 3.43 & 86.67 \\
\hline 5 & LokkoTarra(natural caves) & 2.83 & 3.37 & 83.90 \\
\hline \multicolumn{5}{|c|}{ Tourist Attraction } \\
\hline 7 & Indigenous culture as a tourist attraction & 4.51 & 4.29 & 105.23 \\
\hline 8 & Rambu Solo's rituals and ceremonies & 4.29 & 4.23 & 101.35 \\
\hline 9 & Traditional art performances & 3.03 & 3.60 & 84.13 \\
\hline \multicolumn{5}{|c|}{ Tourism Facilities } \\
\hline 13 & Road condition & 2.43 & 3.97 & 61.15 \\
\hline 14 & Transport mode to tourism objects & 2.71 & 3.66 & 74.22 \\
\hline 15 & Infrastructure & 3.06 & 3.77 & 81.06 \\
\hline \multicolumn{5}{|c|}{ Tourists } \\
\hline 16 & Information & 2.51 & 3.69 & 68.22 \\
\hline 17 & Tour guide services & 2.03 & 3.57 & 56.80 \\
\hline 18 & Tourists' safety & 3.40 & 3.54 & 95.97 \\
\hline \multicolumn{5}{|c|}{ Society } \\
\hline 19 & Community participation & 3.63 & 3.71 & 97.69 \\
\hline 20 & Tourism objects' management and preservation & 3.29 & 4.00 & 82.14 \\
\hline
\end{tabular}


Based upon the IPA analysis and also by considering the satisfaction and importance value of the tourism components variables in table 5, the distribution of each attribute is depicted in a Cartesian coordinate diagram below (Fig. 9).

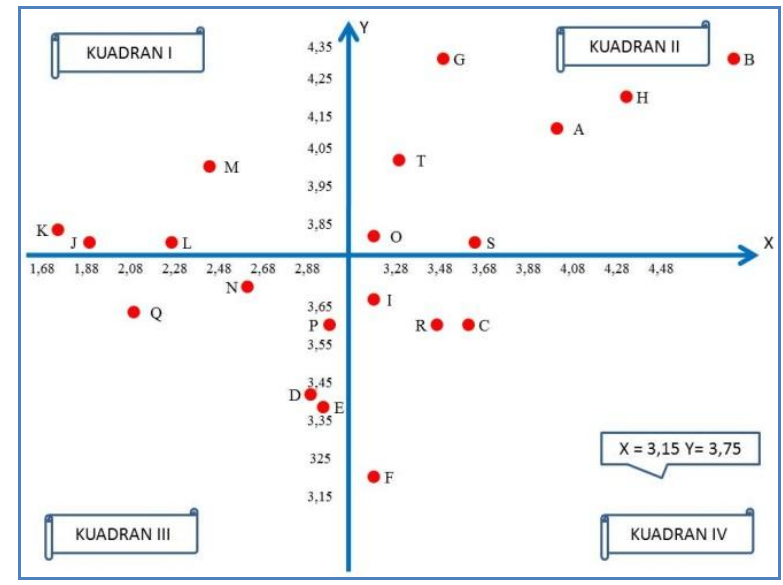

Figure 9. The distribution of tourist satisfaction towards Buntula'bi Sub-villaget attraction.

Legend:

A. Natural beauty

B. Ancient buildings

C. Kollo-kollo museum

D. RanteTendan

E. LokkoTarra natural caves

F. Liang Tondon

G. Indigenous culture as a tourist attraction

H. Rambu Solo's rituals and ceremonies

I. Traditional art performances

J. Restaurants and accommodation

K. Souvenir shops

L. Public facilities (toilets and garbage bins)

M. Road condition

N. Transportation modes to tourism objects

O. Infrastructure

P. Information

Q. Tour guide service

R. Tourists' safety

S. Community participation

T. Tourism objects' management and preservation.

The output of this analysis suggests improvement priority based upon the distribution of each attribute in each quadrant [9]. The detailed explanation of the quadrants is as follow:

- Quadrant I, Concentrate here (top priority): including 4 attributes, i.e. public facilities, road condition, restaurants and accommodation, and souvenir shops.

- Quadrant II, Keep up the good work, including 7 attributes i.e. Natural beauty, ancient buildings, the indigenous culture as a tourist attraction, Rambu Solo's rituals and ceremonies, infrastructure, community participation, and the tourism objects' management and preservation.

- Quadrant III, low priority, including 5 attributes, i.e. Rantetendan, LokkoTarra natural caves, transportation modes to tourism objects, information, and tour guide services.

- Quadrant IV, possible to overkill (excessive), including 4 attributes i.e. KolloKollo museum, Liang Tondon, traditional art performances, and tourists' safety.

Tourism development strategy based on the perception of Buntula'bi tourists

Based on the IPA analysis, the alternative strategy for tourism development in Buntula'bi Hamlet can be elaborated to the following:

Quadrant I, concentrate here/top priority (high importance level, low satisfaction level). The strategies are:

- Improving the public facilities such as toilets and garbage bins to support tourist amenities.

- Optimizing the road conditions (especially the Balusu axis) to provide better access to Buntula'bi.

- Developing restaurants and accommodations.

- Developing souvenir shops.

Quadrant II, keep up the good work/keep achievement (both high importance and satisfaction level). The strategies are:

- Preserving and maintaining the natural environment.

- Preserving traditional characteristics and values of both buildings and villages.

- Preserving and maintaining indigenous culture as a tourist attraction.

- Preserving and maintaining the traditional rituals and ceremonies of Rambu Solo'.

- Maintaining the infrastructure such as roads (access), drainage, water supply, communication in Buntula'bi.

- Maintaining community participation by involving them in the environment restoration and preservation processes.

- Maintaining all kinds of tourism objects to boost tourist attraction.

Quadrant III, low priority (low important and satisfaction level), the directions are:

- Restoring the function of Rante Tendan as a venue for traditional ceremonies such as Rambu Solo', besides Rantelssun. 
- Designating the natural cave of Tarra Lokko as the burial site for the common people of Buntula'bi.

- Granting public transportation access to the objects for easier accessibility.

- Providing sufficient information about tourism objects.

- Providing additional tour guide services; though tourists are satisfied with the current availability of local tour guides.

Quadrant IV, possible to overkill/excessive (low importance level, yet high satisfaction level).

- Sustaining the maintenance of the Kollo-Kollo museum.

- Sustaining the maintenance of Liang Tondon as a burial place for the nobles in Buntula'bi.

- Sustaining support for the dance studio and pa'katia (a guest welcoming group) for art performances.

- Ensuring tourists' safety by maintaining indigenous values of Buntula'bi as a safe and secure traditional neighborhood.

\section{CONCLUSION}

The tourism potential in Buntula'bi Sub-village is a constitution of ancient buildings and traditional environment. Based upon the IPA analysis, the top priorities in tourism development strategy are formulated to:

- Improve public facilities

- Optimize road condition for better access

- Develop more restaurants and accommodations

- Develop souvenir shops

Also given the good performing aspects in Quadrant II (keep up the good work), the tourism developments strategy in Buntula'bi should also be taken to:

- Maintain and take care for the natural beauty

- Maintain the characteristics of ancient buildings

- Maintain the attractive activities (local heritage) as the tourist attraction

- Maintain the rituals and ceremonies such as Rambu Solo'.

- Maintain the internal utilities

- Maintain the community involvement in the restoration and conservation of environment

- Maintain and keep the attraction as a form of management and protection of attraction.

\section{REFERENCES}

[1]. Sarm, C. 2013. Managing interpretation at UNESCO World Heritage Site: A supplay-side perspective of Angkor Wat Temple, Cambodia. Master Thesis. Master Of Tourism Management, Victoria University of Wellington.

[2]. Sugiyono. 2009. Research methods quantitative, qualitative and R\&D. Bandung. Alfa Beta.

[3]. Arikunto, S. 2006. Research procedure, A practical approach. Jakarta. RinekeCipta.

[4]. Sari, E.S. 1999. Audience research. Jakarta. Ghalia Indonesia.

[5]. Martilla, J.A., and James, J.C. 1977. Importance Performance Analysis. Journal of Marketing 41, 77-79.

[6]. Bacon, D. 2003. A comparison of approaches to Importance - Performance Analysis. International Journal of Market Research XXXV(2), 55-71.

[7]. Palebangan, F.B. 2007. Aluk, Mores of Toraja. Tana Toraja. Sulo Publisher.

[8]. Tulak, D. 2008. Kada Disedan Sarong Bisara DiToke' Tambane Baka. Tana Toraja. Tourism and Cultural Agency.

[9]. Yoeti, and Oka, A. 1996. Introduction to tourism science. Bandung. Angkasa. 